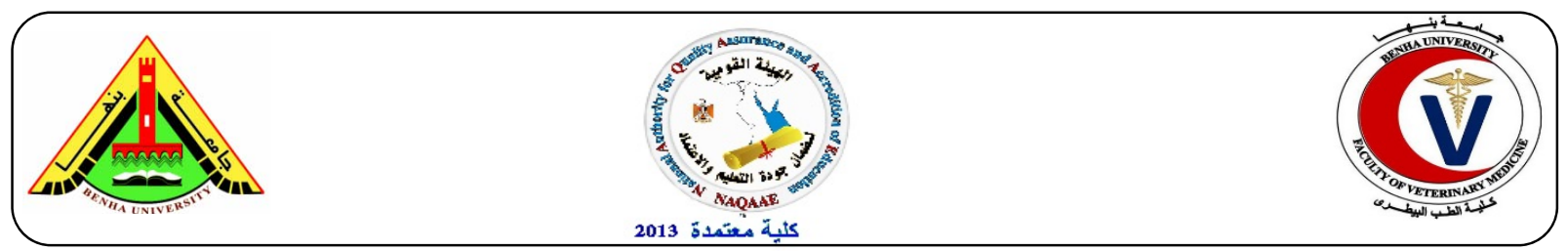

\title{
Pathological and biochemical studies on ochratoxicosis in balady duckling with trail of treatment
}

\author{
Abo El -Fetouh, E.H. ${ }^{1}$; Heba, M.A. ${ }^{1}$, Halla, S. ${ }^{2}$, Ghada, M. El Kader ${ }^{2}$ and Nahed A. kamora ${ }^{3}$ \\ Histopathology ${ }^{1}$, biochemistry ${ }^{2}$ and clinical pathology ${ }^{3}$ departments, Animal Health Research Institute (Zagazig branches)
}

\section{A B S T R A C T}

A total of 100 healthy balady ducklings, one day old were divided into 4 equal groups (25 in each), Gp (1) kept as control group, Gp (2 and 3) received $0.5 \mathrm{mg}$ ochratoxin $/ \mathrm{kg}$ ration and $0.5 \mathrm{ml}$ antiochratoxin/liter drinking water for 30 consecutive days respectively and $\mathrm{Gp}(4)$ received both ochratoxin and antiochratoxin in same dose, period and route of administration. Ducklings supplemented with ochratoxin displayed significant reduction in weight gain, feed conversion rate, RBCs, WBCs, Hb, PCV, T protein albumin, globulin, T. lipid, cholesterol, triglycerides CAT and SOD, coupled with significant elevatoin in feed conversion rate, mortality rate, AST, ALT, ALP, uric acid, creatinine and MDA Ducklings received antiochratoxin showed significant increase in weight gain, RBCs, Hb, total protein, albumin Catalase and super oxide dismutase beside in signif- icant increase in PCV,WBCs, globulin, AST, ALT, ALP, uric acid and creatinine, triglycerides cholesterol and total lipid coupled with insignificant decrease in MDA and improved in feed conversion rate. Hemato-biochemical profiles and antioxidant revealed significant improvement in antiochratoxin treated duckings when compared with ochratoxinated duckings. Ochratoxin residues in liver and kidney were high at $1^{\text {st }}$ day of clearance period and disappeared at $10^{\text {th }}$ days of clearance period. Alteration in histological picture in internal organ in duckling received ochratoxin revealed massive degenerative changes in renal epithelial cells of proximal and distal convoluted tubules (Nephrotoxicity) and massive necrosis of some tubular epithelial cells. Beside severe hepatic damage and also lesions in the immune organs and intestine. In general, histological changes were mild in birds receiving antiochratoxin alone or with ochratoxin. It could be concluded that, ochratoxicosis in duckling resulted in poor feed intake, weight gain and feed conversion rate, had adverse effect in body weight, hemato-biochemical parameters beside decreased blood antioxidant; anti-ochratoxin improved these parameters in duck.

Keywords: duckling, Ochratoxin, body weight, mortality rate, blood picture, biochemical parameters, antioxidant enzymes, Pathology.

(http://www.bvmj.bu.edu.eg)

(BVMJ-31(1): 159-166, 2016)

\section{INTRODUCTION}

Mycotoxins are often found as natural contaminants in grains as secondary metabolites of fungi with major threat to livestock and human beings (Sinha, 1972). The mycotoxins include a complex group of chemical substances causing problems in poultry farms (Schwrdt et al., 2007 ). The family of ochratoxins consists of three members known as ochratoxin $\mathrm{A}, \mathrm{B}$ and $\mathrm{C}$ but ochratoxin $\mathrm{A}$ is the most toxic one causing many adverse effects in domestic livestock causing subacute and chronic production losses in poultry (Huff et al., 2006 ). Ochratoxin interfere with synthesis of enzymes and other proteins by competitively inhibiting phenylalanine-tRNA (Pattison et al., 2008). Ochratoxins are nephrotoxic, carcinogens and immunotoxins in rats and human (Zahoor et al., 2012). Ochratoxin reduce growth rate, immune responses and increase the mortality rate (Tansakul et al., 2012). Decreased humoral immune response to suppression of phagocytosis and poor response to vaccines are common manifestations of ochratoxicosis (Girish and Smith, 2008). The present study was done to evaluate the toxic effects of ochratoxin alone on body performance, hematolo-biochemical and pathological changes in balady duckling and modultion this toxic effect using antiochratoxin.

\section{MATERIALS AND METHODS}

\subsection{Anti-ochratoxin}

It is produced under trade name Texal from Miles Company (Aspania) iumported by Optima Compay, $6^{\text {th }}$ october, Egypt, compound consisted of pure oligosaccharide, lactobacillus, 'actic acid and yeast. 
Ochratoxin A was obtained from microbiology Dep. Fac. of Vet. Med. Zag. Univ.

\subsection{Ducklings and Experimental design}

One hundred balady duckling, one day old, average weight $50 \mathrm{gm}$ were housed under hygienic condition, fed on freshly formulated balanced ration free from any mycotoxin residues and given water ad-libitum. Duckling were divided into 4 groups (25 ducks each), Gp (1) (control group), Gp (2) received $0.5 \mathrm{mg}$ ochratoxin $/ \mathrm{kg}$ ration, $\mathrm{Gp}(3)$ received $0.5 \mathrm{ml}$ antiochratoxin /liter drinking water for 30 consecutive days and $\mathrm{Gp}$ (4) received ochratoxin $(0.5 \mathrm{mg} / \mathrm{kg}$ ration $)$ plus antiochratoxin $(0.5 \mathrm{ml}$ antiochratoxin/liter) in same period and rout. Supplementation of ochratoxin and antiochratoxin for 30 days (from $1^{\text {st }}$ day of age up to $30^{\text {th }}$ day of age). Mortality rate was recoded in all groups from start of experiment to 30 day of age. Body weight: Five ducklings in each group were weighted individually at start of the experiment ( $1^{\text {st }}$ day of age) $\&$ at $1^{\text {st }}$ day post Supplementation ( $31^{\text {th }}$ day of age), consumed ration was recorded for calculation of weight gain and feed conversion rate (FCR)

\subsection{Sampling}

At $1^{\text {st }}$ day post supplementation ( $31^{\text {th }}$ day of age) five ducklings from each group were slaughtered and two blood samples were collected. $1^{\text {st }}$ sample was taken in tube contain EDTA as anticoagulant for estimation estimation (RBCs, $\mathrm{Hb}, \mathrm{PCV} \%$ and TWCs) (Jain, 2000), catalase (CAT) (Solcan, et al. 2008) superoxidase dismutase (SOD) (Palabiyik, et al. 2013) Malonodialdehyde (MDA) (Esterbauer, 1982). The $2^{\text {nd }}$ sample was taken to obtain clear serum for estimation of total protein (Doumas, et al. 1981), albumin (Drupt, 1974), globulin was calculated as difference between total protein and albumin, total lipid (Knight, et al.1972), triglyceride (Royer, 1969), cholesterol [43], transaminases (AST and ALT) (Reitman and Frankel 1957), ALP (John, 1982), Uric acid (Coalombe and Faurean, 1963 ) and creatinine (Husdan and Rapoport, 1968).

\subsection{Ochratoxin residue:}

At $1^{\text {st }}, 5,10^{\text {th }}$ and $15^{\text {th }}$ day post ochratoxin, 3 ducklings from each group were slaughtered and sample from liver and kidneys were taken for determination of ochratoxin residues (Jùrgensen, 2004 ).

\subsection{Pathological examination}

Specimens were taken from liver, kidneys, intestine, spleen and bursa of the sacrificed duckling and directly fixed in $10 \%$ neutral buffered formalin. Five-micron thick paraffin sections were prepared stained with hematoxylin and eosin and examined microscopically (Bancroft and Gamble, 2002).

\subsection{Statistical analysis}

The obtained data was analyzed according to Petrie and Watson (1999).

\section{RESULTS}

Mortality rate Body performance, hematobiochemical parameters and ochratoxin residues were recorded in tables (1-5). Grossly, liver and kidney OF duck received ochratoxin (Gp 2) were enlarged, cyanosed and some cases pale in color. The gall balder enlarged and filled by bile macroscopically change in Gp 2 were sever, the kidney in showed coagulative necrosis of some renal tubule, severe congestion and hemorrhage (Fig, 1). Kidney showed coagulative necrosis of the renal tubules accompanied by lymphocytic aggregations (Fig, 2). Kidney showed severe hydropic degenerative changes in the renal tubules, beside vacular and hydropic degeneration (Fig, 3). Kidney showing perivascular edema and nephritis (Fig, 4). The hepatic tissue showed toxic hepatitis manifested by extravasated erythrocytes, leukocytic infiltration and vacular degeneration accompanied by interstitial fibrosis (Fig, 5). Bursa of fabricius showed lymphocytic depletion and hyperplasia of the mucosal lining epithelium (Fig, 6). Spleen showed necrosis, perivascular edema and lymphoid depletion (Fig, 7), intestine showed epithelial desquamation and necrosis (Fig, 8), kidney showed congestion, vacular and hydropic degeneration as well as lymphocytic infiltration (Fig, 9). The histopathological changes that noticed in the group 4 become mild or less severe the bile ductule showed proliferation portal to portal lymphocytic infiltration (Fig, 10). Intestine showed leukocytic infiltration and periglandular fibrosis (Fig, 11). Bursa of fabricius showed nearly normal structure (Fig, 12).

\section{DISCUSSION}

In the present study ochratoxin resulted in significant increase in mortality rate 7 (17.50\%). Ochratoxin induce about $12.98 \%$ mortality in broilers (Kumar et al., 2003). Meanwhile it has been found ochratoxin caused significant increase in mortality up to $40 \%$ in turkey poults (Chang et al., 1981). Similar mortality rate was recorded in duckling (Yang et al., 2013).

Ochratoxin induced significant reduction in body weight gain, feed consumption and elevation in FCR in duckling. Antiochratoxin (Texal) induce significant elevation in weight gain beside improved FCR. Reduction in weight gain during ochratoxicosis may be due to adverse effect of ochratoxin in 
Table (1) Effect of Ochratoxin and anti-ochratoxin (Texal) on mortality and body performance in duckling $(\mathrm{n}=5)$

\begin{tabular}{|c|c|c|c|c|c|c|c|c|}
\hline \multirow[t]{2}{*}{ Groups } & \multirow{2}{*}{$\begin{array}{c}\text { Total } \\
\text { No }\end{array}$} & \multicolumn{2}{|c|}{$\begin{array}{l}\text { Mortality } \\
\text { rate }\end{array}$} & \multirow{2}{*}{$\begin{array}{l}\text { Ineasial } \\
\text { B.W(gm) }\end{array}$} & \multirow{2}{*}{$\begin{array}{r}\text { Weight at 1st day PT } \\
(\mathrm{gm})\end{array}$} & \multirow[t]{2}{*}{$\begin{array}{r}\text { BWG } \\
(\mathrm{gm})\end{array}$} & \multirow{2}{*}{$\begin{array}{c}\text { FC } \\
(\mathrm{gm} / \\
\text { ducling })\end{array}$} & \multirow[t]{2}{*}{ FCR } \\
\hline & & No & $\%$ & & & & & \\
\hline Gp (1) & 25 & 00 & 00 & $51.43 \pm 0.59$ & $205.94 \pm 0.84$ & $154.51 \pm 7.57$ & 199.05 & 1.29 \\
\hline Gp (2) & 25 & 7 & 28 & $50.53 \pm 0.62$ & $185.05 \pm 0.93$ & $134.52 \pm 2.42 *$ & 185.14 & 1.37 \\
\hline Gp (3) & 25 & 1 & 4 & $51.49 \pm 0.55$ & $248.17 \pm 0.84$ & $196.68 \pm 8.59 * *$ & 218.42 & 1.11 \\
\hline Gp (4) & 25 & 3 & 12 & $51.05 \pm 0.49$ & $214.74 \pm 0.38$ & $163.69 \pm 7.61$ & 209.27 & 1.28 \\
\hline
\end{tabular}

Table (2) Effect of Ochratoxin and anti-ochratoxin (Texal) on blood picture, in duckling ( $\mathrm{n}=5$ )

\begin{tabular}{ccccc}
\hline Parameter & Control duckling & ochratoxin & Anti- Ochratoxin & Ochratoxin+ anti \\
\hline RBCs $\left(10^{6} / \mathrm{cm} . \mathrm{m}\right)$ & $4.05 \pm 0.18$ & $3.22 \pm 0.20^{*}$ & $5.03 \pm 0.31 *$ & $4.25 \pm 0.42$ \\
$\mathrm{Hb}(\mathrm{gm} / \mathrm{dls})$ & $13.16 \pm 0.78$ & $10.23 \pm 0.60^{*}$ & $15.19 \pm 0.41 *$ & $14.04 \pm 0.64$ \\
P.C.V. $\%$ & $36.31 \pm 0.96$ & $32.16 \pm 0.84^{*}$ & $37.06 \pm 0.42$ & $36.68 \pm 0.82$ \\
TWCs $\left(10^{3} / \mathrm{cmm}\right)$ & $10.04 \pm 0.56$ & $8.86 \pm 0.13^{*}$ & $11.10 \pm 0.73$ & $10.31 \pm 0.69$ \\
\hline \multicolumn{5}{c}{ *Significant at $P \leq 0.05$} \\
\end{tabular}

Table (3): Effect of Ochratoxin and anti-ochratoxin (Texal) on some biochemical parameters, in duckling $(\mathrm{n}=5)$

\begin{tabular}{lccccc}
\hline Parameter & & Gp (1) & Gp (2) & Gp (3) & Gp (4) \\
\hline Protein & T. protein & $5.98 \pm 0.46$ & $4.04 \pm 0.39^{* *}$ & $7.31 \pm 0.37 *$ & $6.03 \pm 0.37$ \\
profile & Albumen & $3.43 \pm 0.22$ & $2.54 \pm 0.24^{*}$ & $4.34 \pm 0.26^{*}$ & $3.64 \pm 0.46$ \\
$(\mathrm{mg} / \mathrm{dl})$ & globulin & $2.55 \pm 0.25$ & $1.50 \pm 0.34^{*}$ & $2.97 \pm 0.15$ & $3.06 \pm 0.24$ \\
Liver & A/G ratio & $1.35 \pm 0.19$ & $1.63 \pm 0.21$ & $1.46 \pm 0.32$ & $1.19 \pm 0.32$ \\
enzymes & AST & $37.05 \pm 1.07$ & $40.38 \pm 0.89^{*}$ & $36.98 \pm 0.94$ & $37.21 \pm 0.86$ \\
$(\mathrm{U} / \mathrm{L})$ & ALT & $31.47 \pm 1.15$ & $36.14 \pm 1.05^{*}$ & $30.42 \pm 0.52$ & $31.65 \pm 0.91$ \\
Kidney & ALP & $36.19 \pm 1.53$ & $42.17 \pm 1.17^{*}$ & $36.05 \pm 0.47$ & $36.44 \pm 0.83$ \\
Function $(\mathrm{mg} / \mathrm{dl})$ & Uric acid & $4.62 \pm 0.33$ & $5.53 \pm 0.21^{*}$ & $4.55 \pm 0.37$ & $4.98 \pm 0.51$ \\
Lipid & Creatinine & $1.04 \pm 0.15$ & $1.55 \pm 0.12^{*}$ & $1.02 \pm 0.16$ & $1.09 \pm 0.23$ \\
profile & total lipid & $632.04 \pm 2.17$ & $625.16 \pm 1.04^{*}$ & $635.21 \pm 1.07$ & $631.07 \pm 1.42$ \\
& triglyceride & $98.52 \pm 1.35$ & $92.05 \pm 1.81 *$ & $99.70 \pm 1.73$ & $96.42 \pm 1.53$ \\
& cholesterol & $149.21 \pm 1.82$ & $142.06 \pm 1.86^{*}$ & $152.32 \pm 1.27$ & $148.72 \pm 1.50$ \\
\hline & & *Significant at $P \leq 0.05$ & &
\end{tabular}

Table (4): Effect of Ochratoxin and anti-ochratoxin (Texal) on some antioxidant enzymes, in duckling $(\mathrm{n}=5)$

\begin{tabular}{ccccc}
\hline Parameter & Gp (1) & Gp (2) & Gp (3) & Gp (4) \\
\hline catalase & $1.83 \pm 0.21$ & $1.05 \pm 0.19^{*}$ & $2.42 \pm 0.14^{*}$ & $2.01 \pm 0.27$ \\
Superoxid dismutase $(\mathrm{U} / \mathrm{mL})$ & $70.10 \pm 0.39$ & $68.52 \pm 0.51^{*}$ & $71.71 \pm 0.34^{*}$ & $70.52 \pm 0.72$ \\
Malondialdehyde (nmol/mL) & $13.57 \pm 0.41$ & $15.26 \pm 0.37 *$ & $13.38 \pm 0.51$ & $13.18 \pm 0.62$ \\
\hline \multicolumn{5}{c}{ *Significant at $\mathrm{P} \leq 0.05$}
\end{tabular}

Table 5) Ochratoxin residus in liver and Kidney (ppm/gm) during and post supplementation of duckling ( $\mathrm{n}=5$ )

\begin{tabular}{ccccccc}
\hline Days post treatment & \multicolumn{2}{c}{ Gp (1) } & \multicolumn{2}{c}{ Gp (2) } & \multicolumn{2}{c}{ Gp (4) } \\
& Liver & Kidney & Liver & Kidney & Liver & Kidney \\
\hline 1 & 00 & 00 & $4.66 \pm 0.22$ & $5.21 \pm 0.36$ & $3.05 \pm 0.42$ & $3.15 \pm 0.31$ \\
5 & 00 & 00 & $1.41 \pm 0.16$ & $1.63 \pm 0.21$ & $0.83 \pm 0.31$ & $0.90 \pm 0.15$ \\
10 & 00 & 00 & ND & ND & ND & ND \\
15 & 00 & 00 & ND & ND & ND & ND \\
\hline \multicolumn{7}{c}{ ND= Non-detected }
\end{tabular}



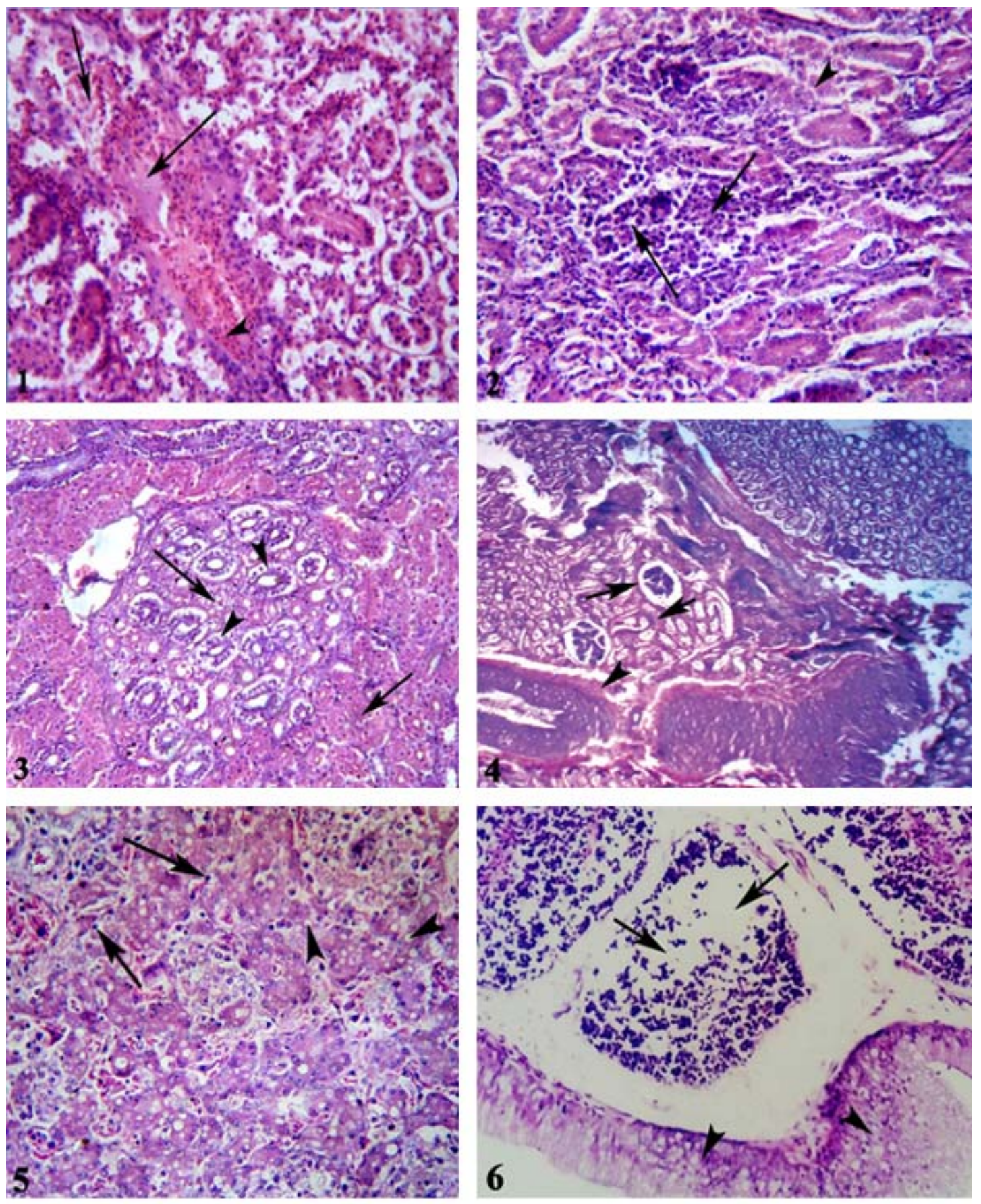

Fig, 1, kidney of duckling in Gp 2 showing coagulative necrosis of some renal tubule, severe congestion and hemorrhage (H\&EX400). Fig, 2, kidney of duckling in Gp 2 showing coagulative necrosis of the renal tubules accompanied by lymphocytic aggregations (H\&EX400). Fig, 3, kidney of duckling in Gp 2 showing severe hydropic degeneration in the renal tubules, beside vacuolar and hydropic degeneration (H\&EX400). Fig, 4, kidney of duckling in Gp 2 showing perivascular edema and nephritis (H\&EX200). Fig, 5, liver of duckling in Gp 2 showing toxic hepatitis manifested by extravasated erythrocytes, leukocytic infiltration and vacuolar degeneration accompanied by interstitial fibrosis (H\&EX400). Fig, 6, bursa of fabricius of duckling in Gp 2 showing lymphocytic depletion and hyperplasia of the mucosal lining epithelium (H\&EX600) 

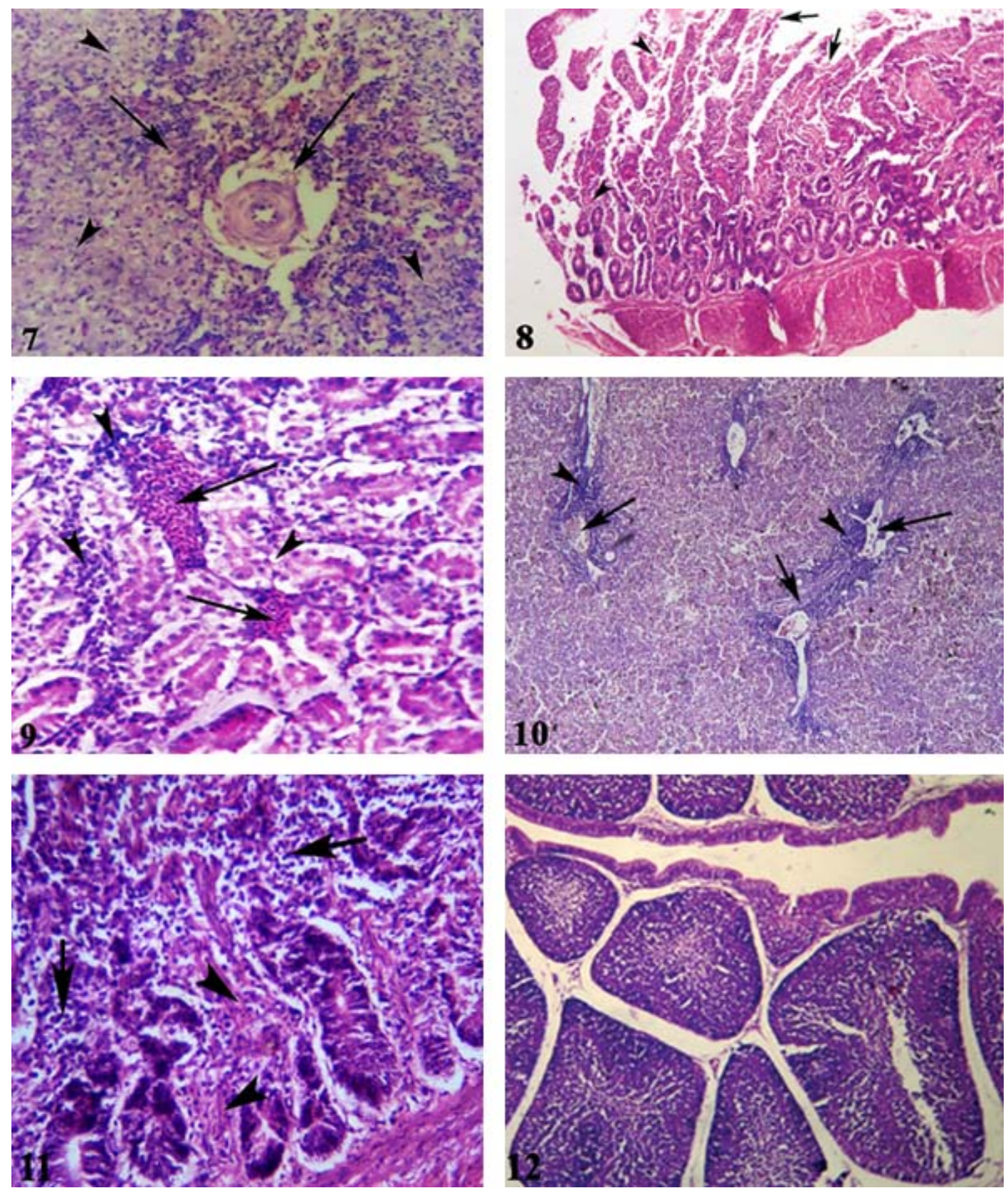

Fig, 7, spleen of duckling in Gp 2 showing necrosis, perivascular edema and lymphoid depletion (H\&EX600) Fig, 8, intestine of duckling in Gp 2 showing severe epithelial desquamation and necrosis (H\&EX300). Fig, 9, kidney of duckling in Gp 4 showing congestion, vacuolar and hydropic degeneration as well as lymphocytic infiltration (H\&EX400). Fig, 10, liver of duckling in Gp 4 showing bile ductule proliferation portal to portal lymphocytic infiltration (H\&EX200). Fig, 11, intestine of duckling in Gp 4 showing leukocytic infiltration and periglandular fibrosis (H\&EX400). Fig, 12, bursa of fabricius of duckling in Gp 4 showing nearly normal structure (H\&EX300).

intestinal tract decreasing feed absorption that led to decrease weight gain alterations (Raju and Devegowda, 2000 ). Reduction in weight gain due to ochratoxicosis was in agreement with previous reports using dietary ochratoxin of broilers (Garcia et al., 2003). Elevation in body weight gain and improved FCR due to oligosaccharide in antiochratoxin due to improved intestinal function or gut health (Huff et al., 1988). Improvement in body performance was found in quail received oligosaccharide (Ghosh et al., 2007 ).

Ochratoxin resulted in significant decrease in Rubs, WBCs, Hb, PCV \% in duckling but Antiochratoxin (Texal) induced significant increase in $\mathrm{RBCs}$ and $\mathrm{Hb}$ beside insignificant increase in 
WBCs and $\mathrm{PCV} \%$ Reduction in RBCs and $\mathrm{Hb}$ content in ochratoxicosis has been noted in broiler chickens (Elaroussi et al., 2006). Reductions in $\mathrm{RBCs}$ and $\mathrm{Hb}$ content may be due to reduction in serum iron in ochratoxicosis (Agag 2004). Reduction in total circulating WBCs during ochratoxicosis, due to decreases in lymphocytes and monocytes (Chang et al., 1981). Change in blood picture post using antiochratoxin may be due to presence of oligosaccharide and lactobacillus. Similar changes in blood picture were previously recorded (Banergee et al., 2002 ) in chickens received oligosaccharides. Same change in erythrogram was recorded in rabbit received oligosaccharides (Bovera et al., 2010).

In the present study, duckling received ochratoxin evoked significant reduction in total protein; albumin and globulin, meanwhile antiochratoxin (Texal) induce significant increase in serum total protein, albumin and globulin. Ochratoxin feeding resulted in dose dependent decrease in total protein and albumin in white leghorn hens (Hassan et al., 2012 ). Reduction in protein profile during ochratoxicosis may be due to reduced feed intake (Raju and Devegowda, 2000 ) and/or due to decline in protein biosynthesis as ochratoxin induce inhibition hepatic protein synthesis (Prior et al., 1980). Oligosaccharide led to a significant increase in serum total protein, albumin and globulin (Shahzad et al., 2014 ).

In the present study, it has been shown that, ochratoxin resulted in a significant increase in the activity of liver enzymes (AST, ALT and ALP), uric acid and creatinine in duckling but antiochratoxin (Texal) induce insignificant effect in liver enzymes (AST ALT and ALP), uric acid and creatinine. Elevated liver enzyme may be due to tissue damage and leakage of enzymes into the blood stream (Sawarkar et al., 2011 ). Our results agreed with Sakhare et al. (2007) who reported that ochratoxin increased uric acid and creatinine in broiler chicks. Ochratoxin induce kidney damage and increased uric acid and creatinine (Raju and Devegowda, 2000 ).

In the present study, it has been shown that ochratoxin induced a significant decrease in serum total lipid, cholesterol and triglycerides. Our results were supported by the results achieved by Elaroussi et al. (2008) mentioned that ochratoxin induce reduction in total lipid, triglycerides and cholesterol in chickens. Ochratoxicosis induce reduction in triglycerides and cholesterol in broiler. Reduction in serum total lipid, cholesterol and triglycerides was reported in ochratoxinated broiler (Schaeffer et al., 1987). Serum total lipid, triglycerides and cholesterol levels of white Pekin ducks were not affected by dietary oligosaccharide [Al-(AlRawashdeh et al., 2000; Costa et al., 2015).
Our results revealed ochratoxin induce significant decrease in CAT and SOD beside significant increase in MDA but antiochratoxin (Texal) induces significant increase in CAT and SOD beside insignificant decrease in MDA. Same observation was recorded stated that ochratoxin induced decreased in CAT and SOD and increase in MDA (Dhanalakshmi et al., 2015; Soyöz et al., 2004 ). Our results go hand in hand with those reported [36] stated that ochratoxin induce decreases in CAT, SOD and elevation in MDA in rat. Change in antioxidant enzymes post using antiochratoxin reported (Singh and Chauhan, 2011).

The main gross pathological lesion appeared in duckling received ochratoxin were enlargement of the liver and kidney. Same gross pathological lesion was observed previously in chickens (Biro et al., 2002). Pathological finding in our work revealed severe lesion in duckling received ochratoxin but in duckling received ochratoxin with antiochratoxin lesions were mild. These lesions were represented by sever nephrogenic change manifested by degenerative change in renal tubule. Hepatic tissue appears suffering from more lesion as congestion, vacuolar and hydrobic degeneration, bile ductule proliferation and necrosis in some cases. Bursa and spleen undergo lymphoid depletion. Intestinal mucosa under go epithelial desquamation and lymphocytic infiltration. Francisco and Maria (2010) reported that ochratoxin induce acute proximal tubular epithelial necrosis in the kidneys and theses lesion could be related to oxidative damage of ochratoxin. Ochratoxin induces degenerative changes in kidney and liver (Solcan et al., 2008 ). Same pathological changes were observed in ochratoxicated ostrich (Elwan et al., 2009).

Ochratoxin residues in liver and kidney were high at $1^{\text {st }}$ day of clearance period and disappeared at $10^{\text {th }}$ days of clearance period. High residue was found in kidney then liver due to fact kidney is the main target organ of ochratoxin (Alvarez et al., 2004). The obtained results coincide with Juszkiewicz et al. (1982) recorded that ochratoxin eliminated within 7 days post ochratoxin removal from the diet. Higher ochratoxin residues in kidneys than in liver (Zahoor et al., 2012).

Our study demonstrated antiochratoxin ameliorates adverse effects of ochratoxin in duckling and providing largely return the body weight gain and feed conversion rate (Agawane and Lonkar, $2004)$, reduction in mortality rate up to $3(7.5 \%)$, erythrogram, total leukocytic count and biochemical parameters toward the normal levels (Farag et al., 2009 ). Such ameliorative effect of ochratoxin could be attributed to oligosaccharide present in 
antiochratoxin (Singh and Chauhan, 2011).

From this study, we concluded that, ochratoxin in duckling resulted in adverse effect in body weight, some hemato-biochemical and antioxidant enzymes parameter, antiochratoxin (Texal) treatment in duckling improved these parameters.

\section{REFERENCES}

Agawane, S.B., Lonkar, P.S., 2004. Effect of probiotic containing Saccharomyces boulardii on experimental ochratoxicosis in broilers: hematobiochemical studies. Journal of veterinary science 5, 359-367.

Al-Rawashdeh, O.F., Gumaa, A.Y., Orban, J.I., Patterson, J.A., Nour, A.Y.M., 2000. Effects of dietary sucrose thermal oligosaccharide caramel on hematological parameters, fibronectin, selected serum biochemical constituents and hormones, and cecal bacterial counts of white Pekin ducks. Acta Vet-Beograd 50, 307-320.

Alvarez, L., Gil, A.G., Ezpeleta, O., Garcia-Jalon, J.A., Lopez de Cerain, A., 2004. Immunotoxic effects of Ochratoxin A in Wistar rats after oral administration. Food and chemical toxicology : an international journal published for the British Industrial Biological Research Association 42, 825834.

Bancroft, J., Gamble, M., 2002. Theory and practice of histological technique, 5th ed. livingston, London, Edinburgh, New york, Phildadelphia, St Louis, Syndeg.

Banergee, S., Patra, B., Bandoypathyay, P., 2002 Change of blood parameters in Carp. Catla catta. J. Aquatic Biol. 17, 79-84.

Biro, K., Solti, L., Barna-Vetro, I., Bago, G., Glavits, R., Szabo, E., Fink-Gremmels, J., 2002. Tissue distribution of ochratoxin A as determined by HPLC and ELISA and histopathological effects in chickens. Avian pathology : journal of the W.V.P.A 31, 141148.

Bovera, F., Nizza, S., Nizza, A., 2010. Effect of oligosaccharides on rabbit performance and some biochemical parameters. World Rabbit Sci. 18, 9-16.

Chang, C.F., Doerr, J.A., Hamilton, P.B., 1981. Experimental ochratoxicosis in turkey poults. Poultry science 60, 114-119.

Coalombe, J., Faurean, 1., 1963 A new simple method for colorimetric determination of urea Clin. Chem. 9, 102-108.

Costa, G.T., Abreu, G.C., Guimaraes, A.B., Vasconcelos, P.R., Guimaraes, S.B., 2015.
Fructo-oligosaccharide effects on serum cholesterol levels. An overview. Acta cirurgica brasileira 30, 366-370.

Dhanalakshmi, S., Sivakumar, S., Niyogi, D., Mukhopadhayay, S., 2015. Protective effect of Picrorrhiza kurroa on ochratoxin A induced oxidative stress in chickens. Indian J of Vet. Pathology 39 232-234.

Elaroussi, M., Mohamed, A., Elgendy, M., El Barkouky, E., Abdou, A., Hatab, M., 2008 Ochratoxicosis in Broiler Chickens: Functional and Histological Changes in Target Organs International J. of Poultry Sci. 7 414- 422.

Elaroussi, M.A., Mohamed, F.R., El Barkouky, E.M., Atta, A.M., Abdou, A.M., Hatab, M.H., 2006. Experimental ochratoxicosis in broiler chickens. Avian pathology : journal of the W.V.P.A 34, 263-269.

Elwan, I., Shalaby, S., Moustafa, A., 2009. pathological studies on mycotoxins in ostrich. SCVMJ X IV 177-184.

Farag, E., Ali, M., Seddiek, S., Sabry, E., 2009 Comparative Efficacy Of Prebiotic MannanOligosaccharide And Diclazuril In Chickens Experimentally Infected With Eimeria tenella. Zag. Vet. J. 37 102-115.

Francisco, C., Maria, R., 2010. Ochratoxin A Producing Species in the Genus Penicillium. Toxins 2 1111-1120

Garcia, A.R., Avila, E., Rosiles, R., Petrone, V.M., 2003. Evaluation of two mycotoxin binders to reduce toxicity of broiler diets containing ochratoxin A and T-2 toxin contaminated grain. Avian Dis 47, 691-699.

Ghosh, H., Halder, G., Samanta, G., Paul, S., Pyne, S., 2007 Effect of dietary organic acid and mannan oligosaccharide on the performance and gut health of Japanese Quail (Coturnix Coturnix Japonica). Asian J. Poult. Sci. 1, 17.

Girish, C.K., Smith, T.K., 2008. Impact of feedborne mycotoxins on avian cell-mediated and humoral immune responses. World Mycotoxin Journal 1, 105-121.

Hassan, Z., Khan, M., Khan, A., Khatoon, A., 2012 Ochratoxicosis in White Leghorn hens: Production and breeding performance Pakistan Vet. J. 32, 57-61.

Huff, G., Huff, W., Tellez. G., 2006 Limited treatment with $\beta-1,3 / 1,6-$ Glucan improved production of broilers challenged with $\mathrm{E}$. coli Poult. Sci. 85, 613-618.

Huff, W.E., Kubena, L.F., Harvey, R.B., 1988. Progression of Ochratoxicosis in BroilerChickens. Poultry science 67, 1139-1146. 
Husdan, H., Rapoport, A., 1968. Estimation of creatinine by the Jaffe reaction. A comparison of three methods. Clinical chemistry 14, 222-238.

Jùrgensen, K., 2004 Content of ochratoxin a in paired kidney and meat samples from healthy Danish slaughter pigs. Food Addit Contam 19, 562-567.

Juszkiewicz, T., Pliszczynska, J., Wisniewska, H., 1982 ochratoxin A in laying hens, tissue deposition and passage into eggs In: Proc. 5th Int. IUPAC Symp. On Mycotoxins and Phytotoxins, Vienna, pp. 325-334.

Pattison, M., McMullin, P., Bradbury, J., Alexander, D., 2008. Poultry Diseases 6 th ed.

Petrie, A., Watson, P., 1999. Statistics for Veterinary and Animal Science 90 - 99 ed. The Black well Sc. Ltd., United Kingdom.

Prior, M.G., O'Neil, J.B., Sisodia, C.S., 1980. Effects of ochratoxin A on growth response and residues in broilers. Poultry science 59, 1254-1257.

Raju, M., Devegowda, G., 2000 Influence of glucomannan on performance and organ morphology, serum biochemistry and hematology in broilers exposed to ochratoxin British Poultry Sci. 41640 -650.

Sakhare, P., Harne, D., Warke, S., Kurkure, N., 2007. Effect of Toxiroak ${ }^{\circledR}$ polyherbal feed supplement during induced aflatoxicosis, ochratoxicosis and combined mycotoxicoses in broilers Vet. Arhiv. 77, 129-146. .

Sawarkar, A., Sonkusale, N., Ravikanth, K., 2011 Experimental ochratoxin induced mixed mycotoxicosis in broilers and its amelioration with herbomineral toxin binder 'toxiroak gold Inter. J. of Poultry Sci. 10 560-566.
Schaeffer, J.L., Tyczkowski, J.K., Hamilton, P.B., 1987. Alterations in carotenoid metabolism during ochratoxicosis in young broiler chickens. Poultry science 66, 318-324.

Schwrdt, G., Holzgr, H., Gek, M., 2007 effect of ochratoxin A on cell death in human proximal tubule or fibroblast cells in primary culture. Toxic. 232 1-12.

Shahzad, M., Khan, A., Aslam, M., Masood, S., 2014 Dimunition of ochratoxin A and aflatoxinB1 toxicity on hematology and serum biochemistry of Japanese quail The J. of Animal \& Plant Sci. 24 1032-1038.

Singh, R., Chauhan, S., 2011. effects of oligosaccharides and probiotic on the total oxidants, total antioxidants, enzymatic antioxidants, liver enzymes, and serum trace minerals in cyclic heatstressed broilers. Poultry science 90, 573-577.

Sinha, A.K., 1972. Colorimetric assay of catalase. Anal Biochem 47, 389-394.

Solcan, C., Coman, G., Oprean, Z., 2008 histological lesions of kidney in ochratoxicosis of chickens Bulletin UASVM, Vet Med 65 91-98.

Soyöz, M., Ozçlik, N., Altuntaş I., 2004 Effect of ochratoxin on lipid peroxi-dation and antioxidant a protective role of melatonin Cell Biol Toxi 20 13-19.

Tansakul, N., Kusujarit, N., Kasorndorkbua, C., Witoonsatian, K., Songserm, T., 2012. The Effect of Low-dose Ochratoxin: A Fed in Ducks on Blood Haematological Profiles and Histopathological Alterations. Asian J Anim Vet Adv 7, 1021-1027.

Zahoor, U., Muhammad, Z., Aisha, K., 2012. Ochratoxicosis in White Leghorn breeder hens: Production and breeding performance Pak Vet J 32 557-561. 